\title{
Aphid-host plant interaction
}

\author{
Reham Z. Sadek ${ }^{*}$, Shereen M. Elbanna, Fayez M. Semida \\ Zoology Department, Faculty of Science, Suez Canal University, Ismailia, Egypt; \\ *Corresponding Author: dr.reham science@hotmail.com
}

Received 25 April 2013; revised 27 May 2013; accepted 4 June 2013

Copyright (C) 2013 Reham Z. Sadek et al. This is an open access article distributed under the Creative Commons Attribution License, which permits unrestricted use, distribution, and reproduction in any medium, provided the original work is properly cited.

\begin{abstract}
Black bean aphid, Aphis fabae (Homoptera; Aphididae) is a serious pest causing crop loss. Plant-aphid interaction is a dynamic system subjected to continual variation and changes. Host plants induce various biochemical and physical defense mechanisms due to aphid feeding. Aphids can overcome plant defenses by enzymatic adaptations and sequestering secondary metabolites produced by the plant within their bodies as a defense against their enemies. Many strategies were developed and evolved by aphids in order to overcome plant defense barriers which allowed them to feed, grow and reproduce on their host plants. This study aimed to aid in better understanding of the effect of altering host plant on specialist and generalist aphid fitness.The influence of plant defense on population development of Aphis fabae was also investigated. Analyses for insect enzymes were also demonstrated in addition to further biochemical studies on host plant defences. Generalists showed different ecological and enzymatic adaptations towards host plants than specialist Aphis fabae. The results were fully discussed in details.
\end{abstract}

Keywords: Insect-Plant Interaction; Aphis fabae; Specialists; Generalists; Enzymes;

Secondary Metabolites

\section{INTRODUCTION}

Aphis fabae has a host-alternating life cycle [1], overwintering on its winter host, spindle (Euonymus europaeus) [2], and migrating in the spring to a wide variety of summer hosts that include bean, sugar and beet $[3,4]$. After settling on the summer host plant, the spring migrant aphid gives birth to wingless females (generalist wingless virginoparae) that undergo several generations of parthenogenetic viviparous reproduction. High population densities on the secondary host plant cause the production of specialist winged virginoparae [4], which migrate to other summer host plants to start new colonies.

The first activity of aphids is to determine whether a plant is suitable for them or not [5]. After landing on a plant, aphids ingest phloem sap from their hosts through narrow piercing-sucking mouthparts called stylets [5]. During probing, aphids' stylets form mechanical damage that may influence plant responses to infestation [6].

As a result of aphid stress on plants, plants possess a variety of biochemical and physical defense mechanisms that can deter or poison feeding insects on them $[7,8]$. Many plant secondary metabolites have direct toxic effects on a variety of herbivores and pathogens, known from studies in vitro, while other plant defenses appear to have indirect effects upon pests and pathogens, such as in attracting predators and inhibiting insect oviposition [9]. Secondary metabolites have antixenotic or antibiotic properties [10] and plant volatiles that repel PFIs (phloem feeding insects) or attract their natural enemies [11].

Special herbivores including aphids can overcome certain plant defenses by releasing certain enzymes such as mixed function oxidases (MFOs) group in order to detoxify harmful plant compounds by catalyzing oxidative reactions $[12,13]$. In addition, sequestering chemical toxins as secondary metabolites produced by the plant within their bodies to overcome plant defense barriers which allow them to feed, grow and reproduce on their host plants $[14,15]$ and use as a defense against their own enemies [16].

Aphids that feed on plant sap have several enzymatic proteins as phenol oxidases, hydrolases, peroxidases, acetyl choline esterases, glucosidases and esterases [17]. Enzymatic studies reveal that generalist and specialist Aphis fabae have different enzymes according to their host plant. This study aims to aid in better understanding of the effect of altering host plant on specialist and generalist aphid fitness. 


\section{MATERIALS AND METHODS}

\subsection{Plants and Insect Rearing}

Fresh plants or planted seeds for Vicia fabae, Zea mays and Cynanchum acutum were obtained approximately every two weeks from field and some aphids were transferred to the new plants in order to keep stock colony of aphids healthy. 15 plant pots were set up under the laboratory conditions for each experiment. Aphids from Elsharkya governorate were brought to supply this study. A stock culture of Aphis fabae was reared on tick bean seedlings (Vicia faba L.) in environmental cabinets at $15^{\circ} \mathrm{C}-20^{\circ} \mathrm{C}$ and LD 16:8 h photoperiod [18]. After colony establishment for both specialist and generalist on the new plant, Aphis fabae population growth and different signs of infestation stress on host plants were monitored.

\subsection{Aphid Growth Rate Experiments}

The whole related experiments were conducted in a growth chamber under the $20^{\circ} \mathrm{C}, 60 \% \pm 10 \%$ R.H. and a photoperiod of 16:8 (L:D). In order to assess the development duration and survivorship of immature stages, birth weight, adult weight, number of molts and adult longevity, adult apterous aphids were randomly selected from the Aphis fabae stock and placed on the leaf surface inside the leaf Petri cages $(9 \mathrm{~cm}$ in diameter $1.5 \mathrm{~cm}$ in height) using a fine-hair brush [19]. They were then allowed to produce nymphs for 24 hours period. After this time, the adults were omitted and only a cohort of three or four newly born nymphs retained together into each Petri cage [20]. These remaining nymphs were monitored daily in Cellulase cage [20] until reaching adult to assess developmental time and survivorship on all cultivars. The immature become adults, they were observed for reproduction and survival. The same experiment was carried out for winged alatae under specialist rearing conditions.

Five pots (replica) per entry, each containing one plant, were used in a randomized block design in the greenhouse conditions (no overcrowding - 16L:8D intervals$20^{\circ} \mathrm{C}$ temperature for generalist apterous Aphis fabae) and (overcrowding $\longrightarrow 25^{\circ} \mathrm{C}$ temperature-12L:12D for specilalist winged alatae). Each plant was covered with cellulase cage with large ventilation windows, covered with gauze.

Hundred fifty apterous $A$. fabae were distributed evenly over each of the plant trays giving a mean infestation of five $A$. fabae per plant. The Chi-squared test using SPSS procedure was used to compare the observed number of $A$. fabae per test entry, per pre-conditioning treatment, using a $4 \times 4$ contingency table.

\subsection{Aphid Reproductivity Measurements}

Daily maintenance was performed to keep the Petri dish habitat healthy. Adequate light is necessary, but we avoided direct sunlight as this may result in overheating.

Aphids were placed in sterile plastic Petri dishes, 25 individuals per each treatment. One feeding plant was added daily in Petri dishes during Experimental Petri dishes were provided with $20^{\circ} \mathrm{C}$ temperature and 16 hours lightning [21]. Aphids were observed for 72 hours, the number of living and dead insects was noted in the protocol daily. In this regard, we selected and transferred only one newly emerged adult to another new leaf Petri cage. Mortality and the number of nymphs produced by the apterous aphid were recorded and the off springs discarded daily until the death of the adult. In this way we evaluated the fecundity of 21 - 25 adult aphids per each cultivar and the same experiment was carried out for winged alatae.

\subsection{Biochemical Analysis of Aphid Enzymes}

Insects were homogenized for biochemical analysis in a chilled glass Teflon tissue homogenizer (ST-2 mechanic-Preczyina, Poland). After homogenation, supernatants were kept in a deep freezer at $-20^{\circ} \mathrm{C}$ till use for biochemical assays. Double beam ultraviolet/visible spectrophotometer (spectronic 1201, Milton Roy Co., USA) was used to measure absorbance of colored substances or metabolic compounds.

Insects were prepared for analysis by being homogenized in distilled water $(50 \mathrm{mg} / 1 \mathrm{ml})$. Homogenates were centrifuged at 8000 r.p.m. for $15 \mathrm{~min}$ at $5^{\circ} \mathrm{C}$ in a refrigerated centrifuge. The deposits were discarded and the supernatants were kept in a deep freezer till use.

All expermints contained 3 - 4 replicates (insects homogenates), and the results of biochemical determinations were pooled from triplicate determinations. The results were analyzed by one-way analysis of variance (ANOVA) using costat statistical software (cohort software, Berkeley). When the ANOVA statistics were significant $(\mathrm{p}<$ 0.01 ), means were compared by the Duncan's multiple range test. .

\subsubsection{Quantitative Determinations of Peroxidase}

Peroxidase activity was determined according to Vetter et al. [22]. To the sample $(220 \mu \mathrm{l})$, in which the color is to be formed, the following reagents are added: $1 \mathrm{ml}$. of $1 \%$ o-phenylenediamine (in 95\% ethyl alcohol, fresh every 4 hours) and $1 \mathrm{ml}$ of $0.3 \%$ hydrogen peroxide (in distilled water).the reaction is allowed to proceed for 5 minutes at which time is stopped by adding $2 \mathrm{ml}$ of saturated sodium bisulfite. The reagent blank for each sample is prepared by adding the dye, followed by the sulfite, and then the hydrogen peroxide. The enzyme is inhibited by the sulfite so that it is inactive when the hydrogen 
peroxide is added.

The starch in the sample and the blank is flocculated by adding $25 \mathrm{ml}$ of $95 \%$ ethyl alcohol. The starch suspension must be swirled continuously during addition of alcohol, so that good flocculation occurs. The samples were then centrifuged at approximately 3000 r.p.m. for 5 minutes [22]. The clear supernatant is decanted into a colorimeter tube and its absorbance recorded at $430 \mathrm{~m} \mu$. The colorimeter is set at $100 \%$ transmittance with the corresponding blank for each sample. The enzyme activity was expressed as the change in absorbance at 430 $\mathrm{m}\left(\Delta \mathrm{OD}_{430}\right) /$ minute/gm fresh weight.

\subsubsection{Phenoloxidase Activity}

Phenoloxidase activity was determined according to a modification of Ishaaya (1971), in a reaction mixture consisting of $0.5 \mathrm{ml}$ phosphate buffer (0.1 M, PH 7), 200 $\mu 1$ enzyme solution and $200 \mu \mathrm{l}$ catechol solution (2\%). Prior to the initiation of the reaction, the substrate and other ingredients of the reaction mixture were separately incubated at the optimum temperature of the reaction $\left(25^{\circ} \mathrm{C}\right)$. Enzyme reaction was initiated by adding catechol solution. Then after exactly $1 \mathrm{~min}$, the optical density was determined. Zero adjustment was against sample blank. The phenol oxidase activity was determined as O.D. units $\times 10^{3}$ at an absorbance of $405 \mathrm{~nm}$ [23].

\subsubsection{B-Glucosidase Activity}

$\beta$-glucosidase activity was measured by assaying glucose liberated by enzymatic hydrolysis of salicin as described by Lindorth (1988). One $\mathrm{ml}$ of the reaction mixture consisted of $200 \mu \mathrm{l}$ enzyme solution, $0.1 \mathrm{M}$ phosphate buffer ( $\mathrm{pH} 6$ ) and $50 \mu$ mole salicin. Mixtures were incubated at $35^{\circ} \mathrm{C}$ for $30 \mathrm{~min}$, then boil for 2 min to stop the reaction [24]. Glucose that liberated by salicin hydrolysis was measured enzymatically by a glucose kit (sigma kit, sigma co.). Optical densities were measured against blank containing boiling enzyme. Enzyme activity was expressed as ug glucose liberated/min/mg protein.

\subsubsection{Esterases Activity}

Alpha esterases ( $\alpha$-esterases) and beta esterases $(\beta$ esterases) were determined according to Van Asperen (1962) using $\alpha$-naphthyl acetate or $\beta$-naphthyl acetate as substrates, respectively. The reaction mixture consisted of $5 \mathrm{ml}$ substrate solution $\left(3 \times 10^{-4} \mathrm{M} \alpha\right.$ - or $\beta$-naphthylace-tate, $1 \%$ acetone and $0.1 \mathrm{M}$ phosphate buffer, $\mathrm{pH} 7$ ) and $20 \mu \mathrm{l}$ of larval homogenate.

The mixture was incubated for exactly $15 \mathrm{~min}$ at $27^{\circ} \mathrm{C}$, then $1 \mathrm{ml}$ of diazoblue color reagent (prepared by mixing 2 parts of $1 \%$ diazoblue B and 5 parts of $5 \%$ sodium lauryl sulphate) was added. The developed color was read at 600 or $555 \mathrm{~nm}$ for $\alpha$ - and $\beta$-naphthol produced from hydrolysis of the substrate, respectively [25].

$\alpha$-and $\beta$-naphthol standard curves were prepared by dissolving $20 \mathrm{mg} \alpha$-or $\beta$-naphthol in $100 \mathrm{ml}$ phosphate buffer, pH7 (stock solution). Ten milliliters of stock solution were diluted up to $100 \mathrm{ml}$ by the buffer. Aliquots of $0.1 \mathrm{ml}, 0.2 \mathrm{ml}, 0.4 \mathrm{ml}, 0.8 \mathrm{ml}$ and $1.6 \mathrm{ml}$ of diluted solution (equal to $2 \mu \mathrm{g}, 4 \mu \mathrm{g}, 8 \mu \mathrm{g}, 16 \mu \mathrm{g}$ and $32 \mu \mathrm{g}$ naphthol) were pipetted into test tubes and completed to $5 \mathrm{ml}$ by phosphate buffer. One milliliter of diazoblue reagent was added and developed color was measured as mentioned before.

\subsubsection{Acetyl Cholinesterase Activity}

Ach-E (acetyl cholinesterase) activity was measured according to the method described by Simpson et al. [26], using acetylcholine bromide (AchBr) as substrate. The reaction mixture contained $200 \mu$ l enzyme solution, 0.5 $\mathrm{ml} 0.067 \mathrm{M}$ phosphate buffer $(\mathrm{pH} 7)$ and $0.5 \mathrm{ml}$ AchBr $(3 \mathrm{mM})$. The test tubes were incubated at $37^{\circ} \mathrm{C}$ for exactly $30 \mathrm{~min} .1 \mathrm{ml}$ of alkaline hydroxylamine (equal volume of $2 \mathrm{M}$ hydroxylamine chloride and $3.5 \mathrm{M} \mathrm{NaOH}$ ) was added to the test tubes. Then $0.5 \mathrm{ml}$ of $\mathrm{Hcl}$ (1 part of conc. $\mathrm{Hcl}$ and 2 parts of $\Delta \mathrm{H}_{2} \mathrm{O}$ ) was added.

The mixture shaken vigorously and allowed to stand for $2 \mathrm{~min}$. $0.5 \mathrm{ml}$ of ferric chloride solution (0.9 $\mathrm{M} \mathrm{Fecl}_{3}$ in $0.1 \mathrm{M} \mathrm{Hcl}$ ) was added and mixed well [26]. The decrease in AchBr resulting from hydrolysis by AchE was read at $515 \mathrm{~nm}$.

\section{RESULTS}

\subsection{Ecological Studies}

\subsubsection{Aphid Fitness \\ - Mortality}

Significant variation in net mortality rate of generalist A. fabae was identified among various host plants $\left(\mathrm{x}^{2}=\right.$ 15.94; d.f. $=2 ; \mathrm{P}<0.0003$ ). The generalist aphids reared on Vicia fabae had the lowest mortality than those on Maize that had the highest mortality while on Toxic spindle mortality was mild (Figure 1(a) and Table 1). The mortality of specialist of $A$. fabae indicated to be significantly different $\left(\mathrm{x}^{2}=15.18\right.$; d.f. $\left.=2 ; \mathrm{P}<0.0005\right)$ with highest mortality on Zea mays and vicia fabae, respectively but lowest mortality on Cynanchum acutum.

\section{- Fecundity}

There was significant differences in generalist $A$. fabae number of offspring observed on three tested host plants $\left(\mathrm{x}^{2}=1067.22 ;\right.$ d.f. $\left.=2 ; \mathrm{P}<0.0001\right)$. The mean numbers of offspring per aphid were recorded in Figure 2(a) and Table 1 that illustrates the highest reproductivity of generalist on $V$. fabae. Similarly, the number of specialist $A$. fabae offspring was significantly different $\left(\mathrm{x}^{2}=68.13\right.$; 


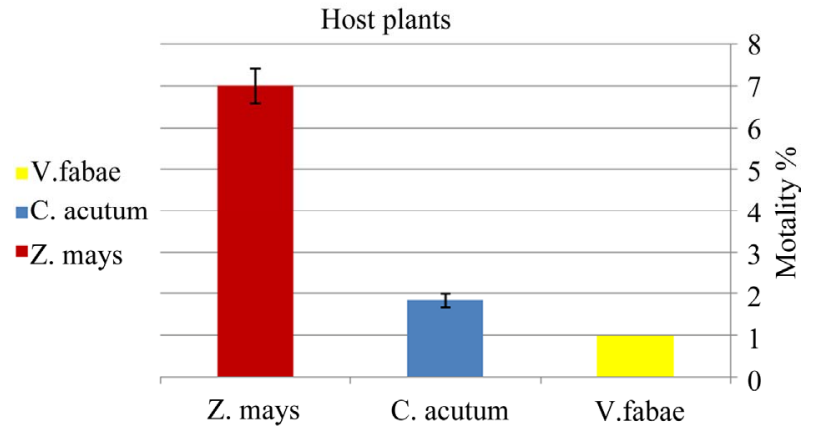

(a)

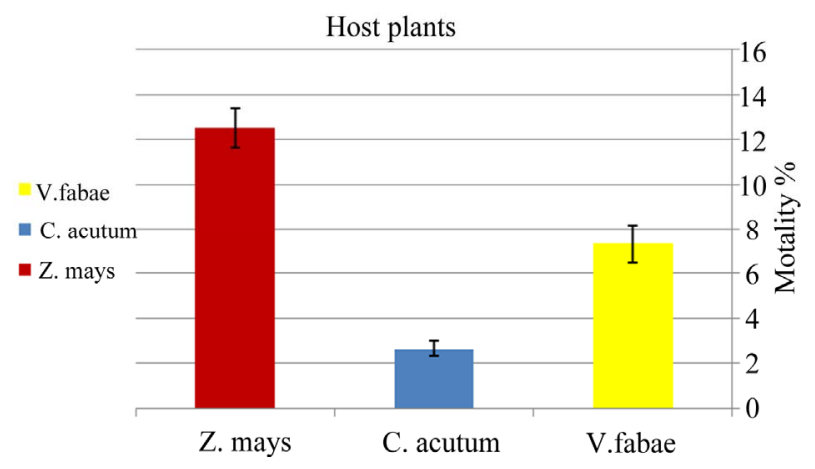

(b)

Figure 1. Difference in mortality \% of generalist Aphis fabae (a) and specialist Aphis fabae (b) on different host plants (mean value \pm S.E.; $(\mathrm{P} \leq 0.05))$.

Table 1. Effect of altering host plants on generalist (G) A. fabae fecundity (number of off-spring along life span), mortality, growth rate (G.R), Birth weight (B.W) (nymph length and width after birth), Adult weigtht (A.W) (adult length and width after maturity), number of mature aphid (M) and developmental time (DT).

\begin{tabular}{cccc}
\hline & \multicolumn{3}{c}{ Host plants } \\
\cline { 2 - 4 } parameters & V.fabae & C. acutum & Z. mays \\
\cline { 2 - 4 } & $(\mathrm{G})$ & $(\mathrm{G})$ & $(\mathrm{G})$ \\
\hline Fecundity & $39.12 \pm 2.57$ & $8.80 \pm 1.30$ & $4.84 \pm 0.82$ \\
Mortality & $1.10 \pm 0.00$ & $1.83 \pm 0.16$ & $7.00 \pm 0.80$ \\
G.R & $24.57 \pm 1.02$ & $20.28 \pm 1.54$ & $0.85 \pm 0.28$ \\
B.W (L) $\mu$ & $76.80 \pm 4.74$ & $76.6 \pm 5.41$ & $42.15 \pm 2.07$ \\
B.W(W) $\mu$ & $43.85 \pm 2.84$ & $42.45 \pm 2.38$ & $23.05 \pm 1.25$ \\
& $113.68 \pm 8.10$ & $67.31 \pm 4.79$ & $33.40 \pm 4.44$ \\
A.W (L) $\mu$ & & & \\
A.W(W) $\mu$ & $67.26 \pm 5.04$ & $40.21 \pm 2.16$ & $20.3 \pm 2.65$ \\
M & $5.00 \pm 0.33$ & $3.25 \pm 0.39$ & $1.5 \pm 0.23$ \\
DT & $11.90 \pm 0.37$ & $4.15 \pm 0.36$ & $2.83 \pm 0.16$ \\
\hline
\end{tabular}

Data represents the mean value \pm S.E. from 25 aphid/group with significance difference between the three different host plants, using Chisquare test $(\mathrm{P} \leq 0.05)$

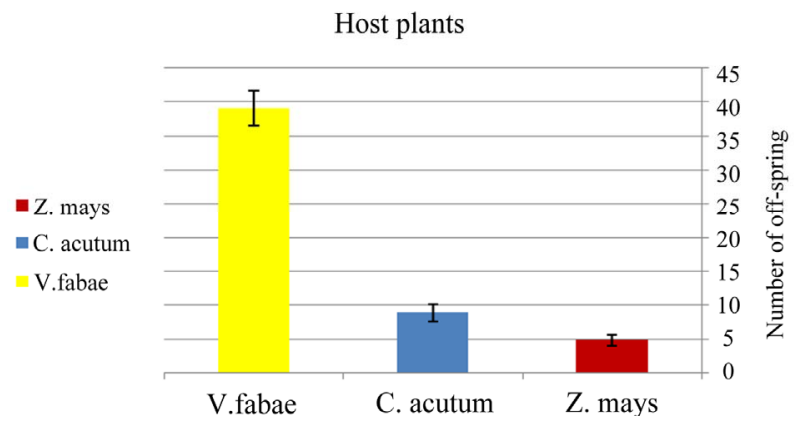

(a)

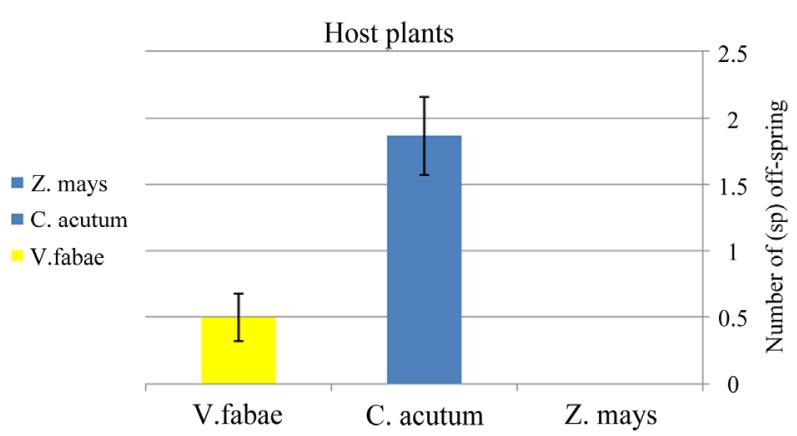

(b)

Figure 2. Reproductivity (number of off spring) of generalist Aphis fabae (a) and specialist Aphis fabae (b) on different host plants under laboratory conditions (mean value \pm S.E.; $\mathrm{P} \leq$ $0.05)$.

d.f. $=2 ; \mathrm{P}<0.0001)$ among cultivars with highest number on Cynanchum acutum than on vicia fabae but no offspring on Zea mays (Figure 2(b) and Table 2).

\subsubsection{Growth Rate}

The laboratory experiments were conducted in a growth chambers for the three host plants indicating that there was significant difference between the measured parameters on generalist and specialist Aphis fabae.

- Developmental time

The development time of generalist immature stages (time from birth until beginning first reproduction) of $A$. fabae varied significantly among the three examined host plants $\left(\mathrm{x}^{2}=9.10\right.$; d.f. $\left.=2 ; \mathrm{P}<0.01\right)$. The mean number of developmental time ranged from 11.9 on Vicia fabae, 4.15 on Cynanchum acutum and 2.83 days on Zea mays (Figure 3(a) and Table 1). The table also demonstrates that the highest number of mature aphid generalist was on bean $\left(x^{2}=7.68 ;\right.$ d.f. $\left.=2 ; \mathrm{P}<0.02\right)$ (Figure 4(a) and Table 1).

Specialist $A$. fabae immature stages reach maturity on Cynanchum acutum in 10 days slower than other host plants with significance difference $\left(\mathrm{x}^{2}=7.6\right.$; d.f. $=2 ; \mathrm{P}<$ 0.02) (Figure 3(b) and Table 2). The number of specialist A.fabae that reached maturity was on Cynanchum acutum higher than number on Zea mays and vicia fabae 


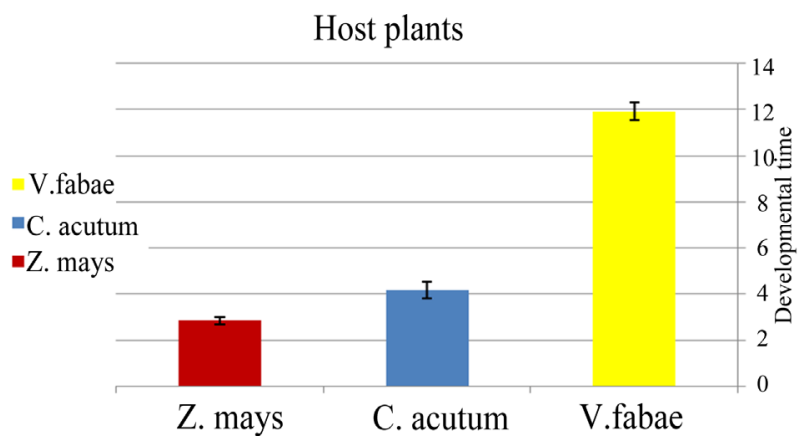

(a)

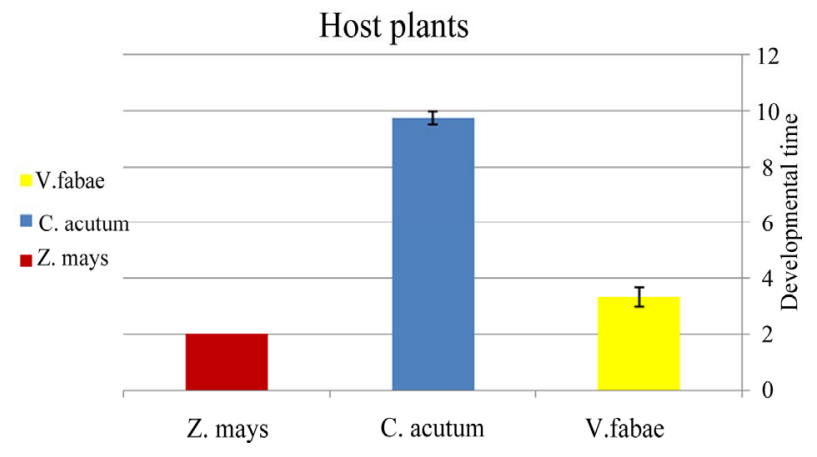

(b)

Figure 3. (a) Difference between generalist developmental time of Aphis fabae (time from birth until beginning first reproduction) and specialist Aphis fabae; (b) on different host plants (mean value \pm S.E.; $\mathrm{P} \leq 0.05$ ).

Table 2. Effect of altering host plants on specialist (Sp) A.fabae fecundity (number of off-spring along life span), mortality, growth rate (G.R), Birth weight(B.W) (nymph length and width after birth), Adult weigtht (A.W) (adult length and width after maturity), number of mature aphid (M) and developmental time (DT).

\begin{tabular}{|c|c|c|c|}
\hline \multirow{3}{*}{ parameters } & \multicolumn{3}{|c|}{ Host plants } \\
\hline & V.fabae & C. acutum & Z. mays \\
\hline & $(\mathrm{Sp})$ & (Sp) & $(\mathrm{Sp})$ \\
\hline Fecundity & $0.5 \pm 0.17$ & $1.86 \pm 0.28$ & $0.00 \pm 0.00$ \\
\hline Mortality & $7.33 \pm 0.84$ & $2.66 \pm 0.33$ & $12.50 \pm 0.86$ \\
\hline G.R & $2.66 \pm 0.23$ & $4.60 \pm 0.36$ & $1.5 \pm 0.28$ \\
\hline \multirow{2}{*}{$\begin{array}{l}\text { B.W(L) } \mu \\
\text { B.W (W) } \mu\end{array}$} & $74.25 \pm 3.16$ & $82.60 \pm 3.99$ & $46.25 \pm 0.69$ \\
\hline & $41.25 \pm 2.03$ & $45.60 \pm 1.79$ & $24.00 \pm 0.99$ \\
\hline \multirow{2}{*}{$\begin{array}{l}\text { A.W(L) } \mu \\
\text { A.W(W) } \mu\end{array}$} & $61.75 \pm 3.61$ & $120.00 \pm 2.10$ & $28.75 \pm 2.61$ \\
\hline & $37.75 \pm 1.83$ & $59.40 \pm 4.02$ & $18.00 \pm 1.37$ \\
\hline M & $2.00 \pm 0.40$ & $7.00 \pm 0.57$ & $1.5 \pm 0.28$ \\
\hline DT & $3.00 \pm 0.33$ & $10.00 \pm 0.24$ & $2.00 \pm 0.00$ \\
\hline
\end{tabular}

Data represents the mean value \pm S.E. from 25 aphid/group with significance difference between the three different host plants, using Chi-square test $(\mathrm{P} \leq 0.05)$.

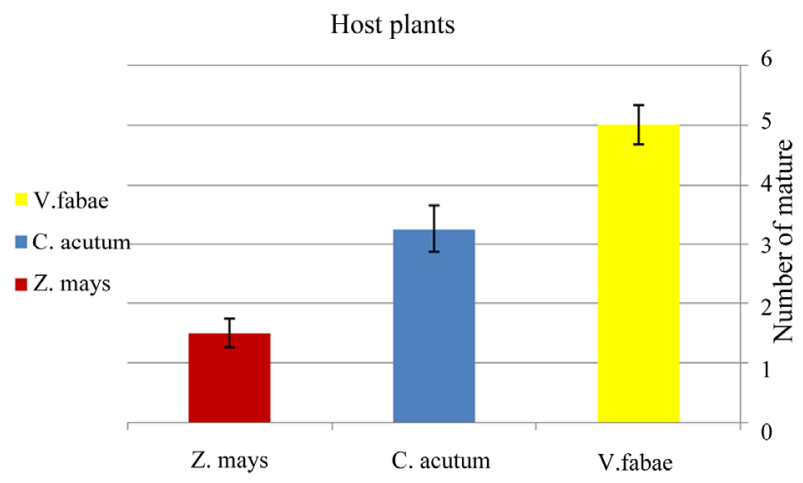

(a)

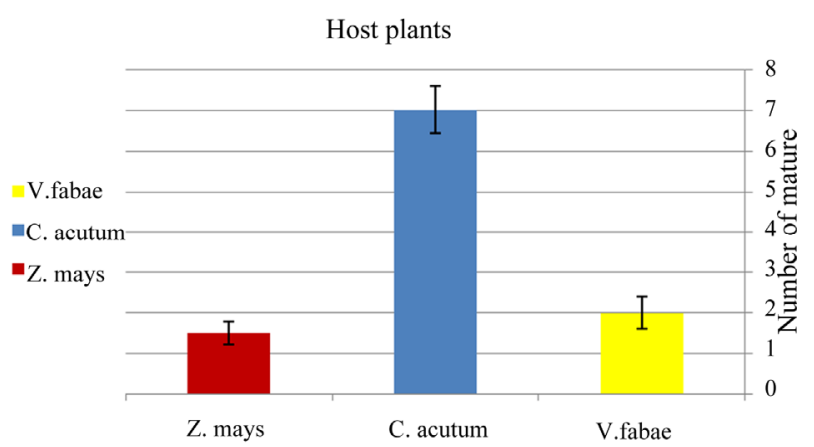

(b)

Figure 4. Difference between number of mature individuals of generalist Aphis fabae/days (a) and specialist Aphis fabae (b) on different host plants (mean value \pm S.E.; $\mathrm{P} \leq 0.05$ ).

respectively "Figure 4(b)" and "Table 2".

\section{- Survival of nymphal stages}

Percentage of specialist survivorship varied from lowest on Zea mays to highest on Cynanchum acutum (Figure 5(b) and Table 2) $\left(\mathrm{x}^{2}=19.12\right.$; d.f. $=2$; $\left.\mathrm{P}<0.0001\right)$. The population growth of generalist (number of offspring from nymph to adult until death) was dissimilar on three different cultivars significantly $\left(\mathrm{x}^{2}=146.73\right.$; d.f. $=2 ; \mathrm{P}<$ 0.0001) (Figure 5(a) and Table 1).

\section{- Birth weight and adult weight}

The comparison between aphid generalist growth rate on different host plants shows that the highest growth rate was on Vicia fabae and lowest on maize. This result was confirmed by the experiment on the aphid size on different host plants which indicate that generalist aphid reared on bean has the largest size (Figure 6(a) and Table 1) $\left(\mathrm{x}^{2}=176.79\right.$; d.f. $=2 ; \mathrm{P}<0.0001$ for length and $\mathrm{x}^{2}$ $=68.1$; d.f. $=2 ; \mathrm{P}<0.0001$ for width) in contrast with specialist aphid reared on $C$. acutum that has the largest size with " $\left(\mathrm{x}^{2}=53.10\right.$; d.f. $=2 ; \mathrm{P}<0.0001$ for length and $\mathrm{x}^{2}=12.18$; d.f. $=2 ; \mathrm{P}<0.002$ for width) (Figure 6(b) and Table 2) .

\subsection{Biochemical Studies}

\subsubsection{Peroxidase Level}

Enzymes analysis revealed that there were high sig- 


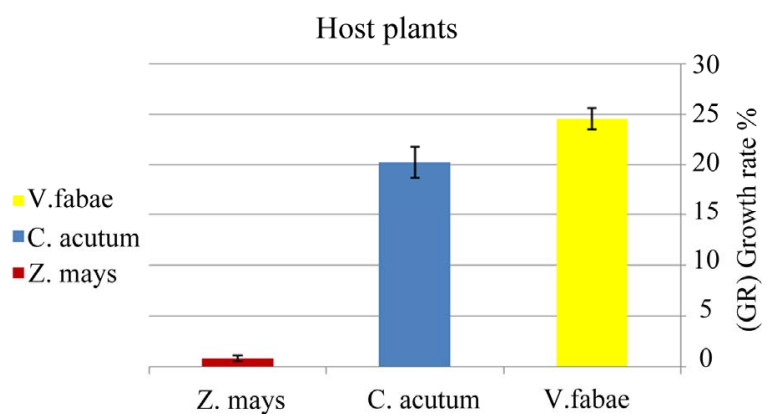

(a)

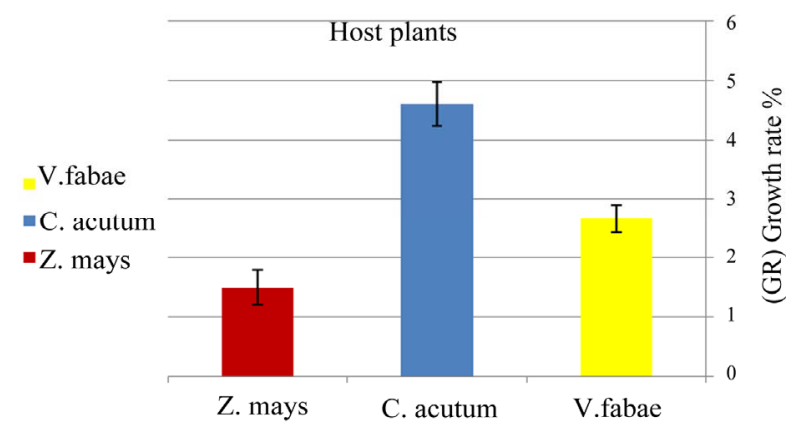

(b)

Figure 5. (a) Difference between population growth rate (G.R) (number of offspring from nymph to adult until death) of generalist and specialist Aphis fabae (b) on different host plants (mean value \pm S.E.; $(\mathrm{P} \leq 0.05)$ ).

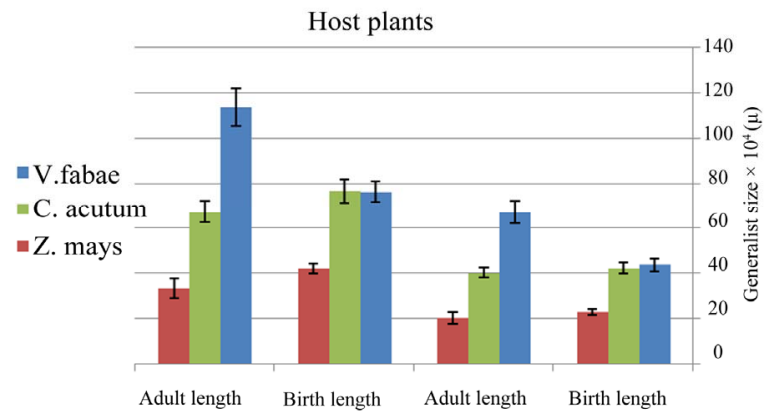

(a)

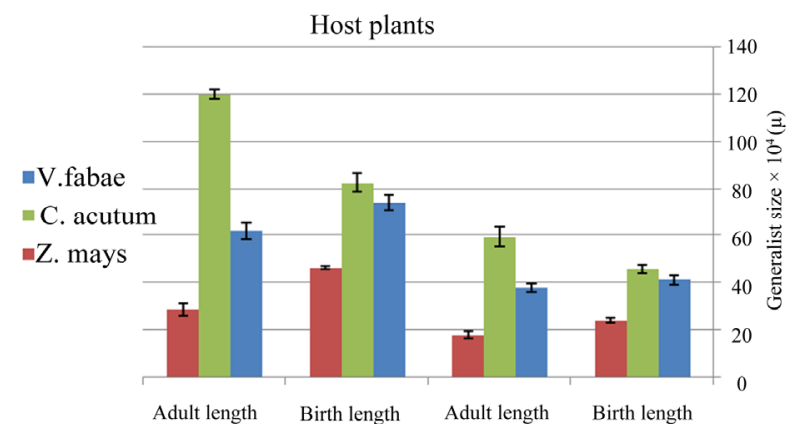

(b)

Figure 6. (a) Difference between size of generalist Aphis fabae and specialist (b) on different host plants (Birth weight (B.W) (nymph length and width after birth), Adult weight (A.W) (adult length and width after maturity)) (mean value \pm S.E.; (P $\leq 0.05)$ ). nificant differences $(\mathrm{P} \leq 0.001)$ in Peroxidase activity of generalist $A$. fabae on the three different host plants. The highest elevation in Peroxidase activity was recorded on $V$. fabae with $\left(\mathrm{F}_{(3,8)}=377.12,(\mathrm{P} \leq 0.001)\right.$ (Figure 7 and Table 3). Specialist Peroxidase level shows increase on C. acutum over that on vicia fabae and Zea mays the difference was highly significant $\left(\mathrm{F}_{(3,8)}=187.80,(\mathrm{P} \leq 0.0001)(\right.$ Figure 8 and Table 4).

\subsubsection{Phenol Oxidase (PO) Level}

Data represented in Figure 7 and Table 3 illustrates that there were alterations in PO level with altering host plants for both generalist and specialist $A$. fabae. There was decline in generalist PO level on Zea mays but increased on $V$. fabae than on $C$. acutum with high significant difference among the three host plants $\left(\mathrm{F}_{(3,8)}\right.$ $=47.05,(\mathrm{P} \leq 0.0002)$. In the specialist group on both $C$. acutum and Zea mays plants results showed high PO enzyme activities than on $V$. fabae (Figure 8 and Table

Table 3. Effect of altering host plants on generalist $(G)$ A. fabae enzymes level (Peroxidase, Phenol-oxidase, Ach-E, Esterase, $\beta$-glucosidase).

\begin{tabular}{cccc}
\hline \multirow{2}{*}{ parameters } & \multicolumn{3}{c}{ Host plants } \\
\cline { 2 - 4 } & $(\mathrm{G})$ & $(\mathrm{G})$ & $(\mathrm{G})$ \\
\cline { 2 - 4 } & $201.33 \pm 5.16$ & $55.93 \pm 2.05$ & $29.16 \pm 1.78$ \\
\hline Peroxidase & $24.83 \pm 1.00$ & $13.35 \pm 0.64$ \\
Phenol oxidase & $37.56 \pm 1.79$ & 24. mays \\
Ach-E & $9.47 \pm 0.23$ & $9.74 \pm 0.26$ & $10.1 \pm 0.17$ \\
Esterase & $93.76 \pm 2.57$ & $62.85 \pm 2.91$ & $57.6 \pm 2.69$ \\
$\beta$-glucosidase & $23.11 \pm 0.43$ & $7.59 \pm 0.36$ & $3.95 \pm 0.21$ \\
\hline
\end{tabular}

Data represents the mean value \pm S.E. of aphid enzymes/group with significance difference between generalist enzymes level on three different host plants, using Chi-square test $(\mathrm{P} \leq 0.05)$.

Table 4. Table Effect of altering host plants on generalist (G) $A$. fabae enzymes level (Peroxidase, Phenol-oxidase, Ach-E, Esterase, $\beta$-glucosidase).

\begin{tabular}{cccc}
\hline \multirow{2}{*}{ parameters } & \multicolumn{3}{c}{ Host plants } \\
\cline { 2 - 4 } & V.fabae & C. acutum & Z. mays \\
\cline { 2 - 4 }$(\mathrm{Sp})$ & $(\mathrm{Sp})$ & $(\mathrm{Sp})$ \\
\hline Peroxidase & $136.83 \pm 3.12$ & $208.66 \pm 6.48$ & $41.42 \pm 2.09$ \\
Phenol oxidase & $5.94 \pm 0.29$ & $28.53 \pm 1.06$ & $25.34 \pm 0.39$ \\
Ach-E & $8.46 \pm 0.23$ & $5.32 \pm 0.11$ & $11.8 \pm 0.10$ \\
Esterase & $56.66 \pm 1.30$ & $64.98 \pm 2.50$ & $45.27 \pm 2.08$ \\
$\beta$-glucosidase & $8.81 \pm 0.39$ & $7.95 \pm 0.18$ & $11.67 \pm 0.56$ \\
\hline
\end{tabular}

Data represents the mean value \pm S.E. of aphid enzymes/group with significance difference between specialist enzymes level on three different host plants, using Chi-square test $(\mathrm{P} \leq 0.05)$. 


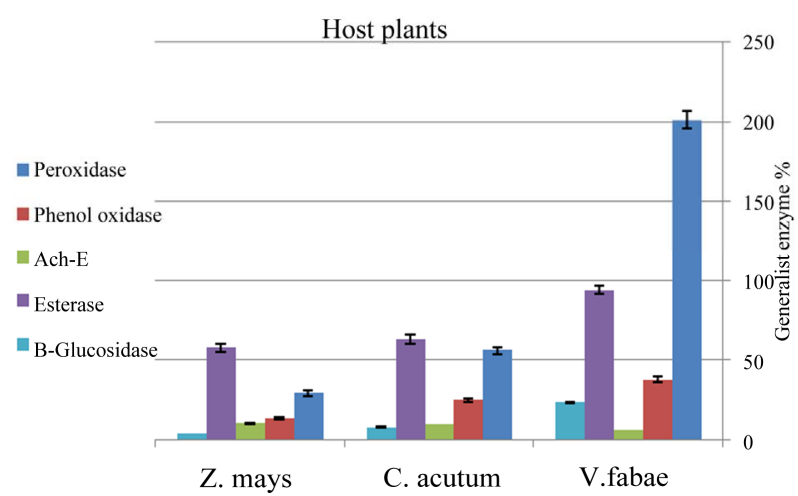

Figure 7. Difference between generalist Aphis fabae enzymes level on three different host plants (mean value \pm S.E.; $(\mathrm{P} \leq$ $0.05)$ ).

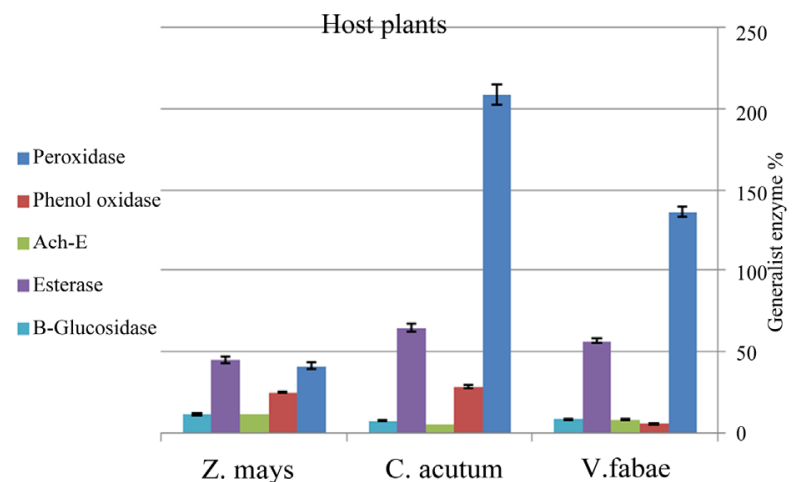

Figure 8. Difference between specialist $A$. fabae enzymes level on three different host plants (mean value \pm S.E.; $(\mathrm{P} \leq 0.05)$ ).

4) indicating high significance difference $\left(\mathrm{F}_{(3,8)}=161.89\right.$, $\mathrm{P} \leq 0.0001)$.

\subsubsection{Acetyl-Choline Esterase (Ach-E) Level}

Generalist aphids Infested resistant Zea mays plants induced significant increase in Ach-E activity than in susceptible C. acutum and $V$. fabae plants $\left(\mathrm{F}_{(3,8)}=70.79\right.$, $(\mathrm{P} \leq 0.0001)$ (Figure 7 and Table 3). All specialist aphids shows Ach-E enzyme activities that were detected in low levels on $C$. acutum and $V$. fabae plants with mean value 5.32 and 8.46 respectively, except that on Zea mays that is the highest with mean value 11.80 (Figure 8 and Table 4) $\left(\mathrm{F}_{(3,8)}=188.86, \mathrm{P} \leq 0.0001\right)$.

\subsubsection{Esterase (E) Level}

Aphid esterases content showed significant change with altering host plants. Highly significant increase were recorded in generalist esterases on $V$. fabae while on C. acutum induced mild esterase content than on Zea (Table 3). There were significant differences in total specialist esterses contents among different host plants (Figure 8 and Table 4) $\left(\mathrm{F}_{(3,8)}=11.92, \mathrm{P} \leq 0.008\right)$. Aphids reared on C. acutum induced more $\mathrm{E}$ than on $V$. fabae and Zea mays respectively.

\subsection{5. $\beta$-Glucosidase $(\beta-G)$ Level}

The results of $\beta$-Glucosidase enzyme assays supported the results of whole-aphid assays representing that $(\beta-\mathrm{G})$ activity (Figure 7 and Table 3) was highly detected in generalist A. fabae reared on $V$. fabae than on C. acutum, but in low content for those on Zea mays showing high significance difference $\left(\mathrm{F}_{(38)}=255.31\right.$, $\mathrm{P}$ $\leq 0.0001)$. There were slightly reductions in specialists $(\beta-\mathrm{G})$ content reared on $C$. acutum than those reared on $V$. fabae and Zea mays with highest value (Figure 8 and Table 4) that vary significantly $\left(\mathrm{F}_{(3,8)}=14.10, \mathrm{P} \leq\right.$ $0.005)$.

\section{DISCUSSION}

The black bean aphid; Aphis fabae (Homoptera; Aphididae) attacks a large number of host species from many plant families such as Leguminoseae and Chnopodiaceae as well as a quantity of weeds as secondary hosts $[27,28]$. The goal of our study was to investigate A. fabae population growth and fitness on three different host plants. The study clearly showed that $V$. fabae was the most suitable host for apterous aphid A. fabae fecundity and longevity due to including the best host quality [29], this is in agreement with [30,31].

The present study revealed that significant induction in the generalist $A$. fabae reproductivity was noticed on $V$. fabae, in addition to significant reductions in the number of specialist $A$. fabae offspring likewise [32] study on $A$. fabae populations indicating that all measured fitness indices are higher on broad bean.

Generalist aphids can cope with induced plant resistance [33] which results in facilitated settling and thus in increased population growth in agreement with [34] on Myzus persicae and [35] demonstrated that $\mathrm{Me}$ goura viciae [Buckton) aphids are able to feed over longer periods on Vicia faba that was confirmed within our data. A similar effect was not observed for M. persicae on Arabidopsis thaliana resistance $12 \mathrm{~h}$ after infestation [36].

The represented data show that aphid fecundity on $C$. acutum represents mild number of generalist offspring than number on $V$. fabae that may be due to the plant $C$. acutum containing toxic latex and chemical compounds as terpenes, alkaloids and glucosinolates present in dicotyledones families [37] that affect both specialist/ generalist aphid species causing changes of reproductive rates, development and performance that are in agreement with [38-40] studies.

Zea mays were the least suitable plant for the development of black bean aphid, it may be due to the fact that the plant containing toxins can reduce the infestation of aphids [28] which are in agreement with [31].

Specialist immature survivorship and growth rate varied from lowest on Zea mays as documented in our 
data and supported by Ogenga [89] showing that maize decrease A. fabae infestations to the highest on $C y$ nanchum acutum that agrees with [41] study on specialist Acyrthosiphon kondoi on M. truncatula Jester and Jemalong indicating that specialist and generalist $A$. $f a$ bae infestations increase according to host quality as some chemicals deter alatae from settling and antibiosis (reduced longevity, growth, and fecundity) as in [41-43]. [17] also investigated the ability of specialist Brevicoryne brassicae to sequester toxic glucosinolates from their host plants specificity in plant molecular, biochemical, and physiological responses to insects which are observed frequently in volatile production [17] act directly to decrease fecundity, enhance or deter feeding, that clearly explains the study results .

Generalist A. fabae reared on Vicia faba and C. acutum inducing $8 \%$ and $44 \%$ mortality respectively with highest immature survival while on resistant $Z$. mays showing $84 \%$ mortality with lowest immature survival since generalists tended to respond to a large array of different plant chemicals and proteins [44-46] that agree with study of Hunter et al. [47] and it was shown by [48] only due to generalist feeding strategy that were able to grow and develop on a variety of host plant species [49]. Specialist $A$. fabae showed highest mortality on both Vicia faba and Z. mays with $88 \%$ and $100 \%$, respectively and lower mortality $16 \%$ on $C$. acutum with highest immature survival. Specialist insect hosting only on a few related plant species might be expected to have a more efficient form of adaptation, either involving the production of large quantities of an enzyme to detoxify their food, or evolve storage mechanisms [50-52]. Shen et al. [53] study revealed that Maize contains both indol and terpene volatiles in addition to having less favorable $\mathrm{PH}$ and nutrient content for aphid than V. fabae as [54] .

The present study indicated that the development time of generalist on $V$. fabae was longer with higher birth weight and adult weight than the specialist aphids developed on C. acutum with reduced birth weight and adult weight as delay in adult emergence may be correlated to ability for prolonged feeding on phloem sieve elements keeping these cells alive and their sieve plate pores open by preventing coagulation of phloem or even days from a single sieve element [55] and proteins [p-proteins] [56] that allow aphids ingest phloem sap [57] and their ability to adapt feeding strategies and avoid or deter many plant defenses.

Aphids avoid plant chemicals and therefore, do generate detoxification enzymes and reduce total glucosinolate levels [44-46]. A reduction in glucosinolate levels creates a more insect-friendly environment for generalists, which are repelled by glucosinolates. However, reduced glucosinolates may be advantageous for spe- cialist aphids that are attracted to and utilize these compounds for their own defense [58]. [17] investigated the ability of specialist Brevicoryne brassicae to sequester toxic glucosinolates from their host plants.

Specialist herbivores adapted to plant chemical defense developing mechanisms. These insects frequently detoxify or sequester plant defense compounds [59] and, sometimes, they result in protection against parasitoids and predators being used as toxic or unpalatable at defense $[15,60]$. Findings in our results indicated insects release antioxidant enzymes after aphid feeding to detoxify these potentially dangerous reactive secondary metabolites. Generalist $A$. fabae enzymes level infesting $V$. fabae increased in Peroxidase and Phenoloxidases activity than others on other non host plants that confirmed by [61]. The reviewed current aphid saliva protein components show some contradictions, not only between species but also within aphid species [62-66] that investigate the variation in enzymes level of both specialist and generalist $A$. fabae.

The signals responsible for the activation of plant defenses to aphid feeding are not only mechanical, but also chemical, through the action of particular enzymes commonly called elicitors which are present in saliva [67]. Goggin (2007) [68] that explain the high level of peroxidase enzyme in generalist aphids feeding on $V$. fabae as a susceptible host plant than C. Acutum and Z.mays respectively and specialist $A$. fabae on C. acutum. [61,69-71] revealed that The salivary enzymes of aphids are similar to enzymes with identical functions in plants, i.e. oxidases and enzymes that depolymerize polysaccharides are injected in very small amounts relative to their counterparts in the plant that agree with peroxidase enzyme level increase on secseptible $V$. fabae for generalist and C. acutum for specialist than other resistant host plants. [72,73] study on Wheat aphid confirmed PO results in order to oxidize plant phenolics and other allelochemicals in its food plants [74] and remove hydrogen peroxide from plants as oxido-reductases, thus creating a more favorable media for reproduction and development that agree with [75].

The same for Phenoloxidase, $\beta$-Glucosidase and Esterases of generalist $A$. fabae enzyme content was indicated in our study coping with $[71,76]$ studies on $\beta$ Glucosidase induction due to Pieris brassicae infestation that induced the release of volatile organic compounds in host plants in present seeds and vegetative organs of leguminous plants [77-79]. The increase in $\beta$-G to overcome the plant induced defensive compounds activity for generalist $A$. fabae but $\beta$-G level decreases for specialists as these compounds increase were more preferable for specialist attraction by suitable host plant as indicated by our study.

Our data showed that Esterases increase in general- 
ists with highest level on $V$. fabae and the same increase for specialist $A$. fabae but with highest level on C. acutum due to their detoxification ability to plant defence compounds in order to adapt to these host plants in agreement with [29] and was investigated in our study results.

Phenol oxidase presented within generalist $A$. fabae on V. fabae which is higher than C. acutum and Z. mays is likely to occur since phloem sap may contain phytochemicals that are produced by the plant for defensive purposes [39] as shown in [80] study in order to deter phenolic compounds that are toxic to aphids and impair their growth, development and fecundity [8183]. In contrast, specialist Phenol oxidases are higher on C. acutum due to their high toxicity and alkaloid content, this is due to ability to sequestering and deploying the poisons as indicated by [84] as well as on Maize due to their high phenolic content that may detoxify them and convert their anti-probing activity in agreement with Studying Papilio polyxenes behavior $[34,79,85,86]$.

ACh-E result coincided with the finding of $[87,88]$ reported decrease in ACh-E in $R$. padi that was correlated to their role in transmission of nerve impulses in order to decrease effect of plant toxins on A. fabae performance and fitness on host plants that were observed to be the same for both generalists and specialists. Observation of enzymatic secretions of alatae (the winged, migratory morph) and gynoprae can reveal clues to ecological studies on aphid resistance, such as whether antixenotic (deterrent) factors present and the influence on aphid foraging behavior.

\section{ACKNOWLEDGEMENTS}

The authors extend thanks to Suez Canal University, Zoology Department, Faculty of Science as well as Plant Protection Research institute for assistance in rearing aphids and biochemical analysis.

\section{REFERENCES}

[1] Powell, G. and Hardie, J. (2001) The chemical ecolgy of aphid host alternation: how do return migrants find the primary host plant? Applied Entomology and Zoology, 36, 259-267. doi:10.1303/aez.2001.259

[2] Thieme, T. (1987) Members of the complex Aphis fabae Scop. and their host plants. In: Holman, J., Pelikan, J., Dixon, A.F.G. and Weissman, L. (Eds.), Population Structure, Genetics and Taxonomy of Aphids and Thysanoptera, SPB Academic Publishing, The Hague, 314-323.

[3] Fereres, A., Avilla, C., Collar, J.L., Duque, M. and Fernandez-Quintanilla, C. (1996) Impact of various yieldreducing agents on open-field sweet peppers. Environmental Entomology, 25, 983-986.

[4] Müller, C.B., Williams, I.S. and Hardie, J. (2001) The role of nutrition, crowding and interspecific interactions in the development of winged aphids. Ecological Entomology, 26, 330-340.

doi:10.1046/j.1365-2311.2001.00321.x

[5] Iwona, M., Van, C.M. and Beata, G. (2011) Phytohormonal signaling in plant responses to aphid feeding. Acta Physiol Plant, Springer.

[6] Tjallingii, W.F. and Hogen Esch, T.H. (1993) Fine-structure of aphid stylet routes in plant-tissues in correlation with EPG signals. Physiological Entomology, 18, 317328. doi:10.1111/j.1365-3032.1993.tb00604.x

[7] Smith, C.M. (1989) Plant resistance to insects: A fundamental approach. John Wiley and Sons, Inc., New York.

[8] Hartley, S.E. and Jones, C.G. (1999) Plant chemistry and herbivory, or why the world is green. In: Olff, V.K., Brown and Drent, R.H. (Eds.), Herbivores: Between Plants and Predators, Blackwell, Oxford.

[9] Shereen, M.E. (2007) Insect interactions of three trophic levels on milkweed plant, Asclepias sinaica (Boiss.) musch. International Journal of Agriculture and Biology, 9, 292293.

[10] Wagner, G.J., Wang, E. and Shepherd, R.W. (2004) New approaches for studying and exploiting an old protuberance, the plant trichome. Annals of Botany, 93, 3-11. doi:10.1093/aob/mch011

[11] Linda, L.W. (2008) Avoiding effective defenses: Strategies employed by phloem-feeding insects. Plant Physiology, 146, 859-866.

[12] Rosenthal, G.A. and Janzen, D.H. (1979) Herbivores: Their interaction with secondary plant metabolites. Academic Press, New York, 41.

[13] Feyereisen, R. (1999) Insect P450 enzymes. Annual Review of Entomology, 44, 507-533. doi:10.1146/annurev.ento.44.1.507

[14] Omodele, I., Runyararo, M.H. and Graeme, B. (2011) Understanding Aphid-Plant Physiological Interactions. University of Fort Hare Press, Alice, 17, 5-45.

[15] Silva, F., Marcia O.M. and Marcio, C. (2002) Plant-insect interactions: An evolutionary arms race between two distinct defense mechanisms. Brazilian Journal of Plant Physiology, 14, 71-81.

[16] Karban, R. and Baldwin, I.T. (1997) Induced responses to herbivory. University Chicago Press, Chicago, 33-38. doi:10.7208/chicago/9780226424972.001.0001

[17] Arimura, G., Kost, C. and Boland, W. (2005) Herbivoreinduced, indirect plant defences. Biochimica et Biophysica Acta, 1734, 91-111. doi:10.1016/j.bbalip.2005.03.001

[18] Joan, C.S. and Maydianne, A. (1994) An investigation of the behavior of the pea aphid, Acyrthosiphon pisum. In: Goldman, C.A., Ed., Tested Studies for Laboratory Teaching, Volume 15 (Goldman, C.A.), Reprinted from: Sharp, J. C. and M. Andrade, Proceedings of the 15th Workshop/ Conference of the Association Biology for Biology Laboratory Education (ABLE), 335-346.

[19] Fred, E.F., Georges, L. and Eric, H. (2004) Olfactory responses to Aphid and host plant volatile releases: (E)- $\beta$ Farnesene an effective kairomone for the predator Adalia 
bipunctata. Journal of Chemical Ecology, 30, 741-755. doi:10.1023/B:JOEC.0000028429.13413.a2

[20] Hartley, E.A. (1923) A useful cage for the rearing of small insects on growing plants. New York State College of Forestry, Syracuse, 201-203.

[21] Halimona, J. and Jankevical, L. (2011) The influence of entomophtorales isolates on Aphis fabae and Metopeurum fuscoviride. Latvijas Entomologs, 50, 55-60.

[22] Vetter, et al. (1958) Quantitative determination of peroxidase in sweet corn. Journal of Agricultural and Food Chemistry, 6, 39-41. doi:10.1021/jf60083a006

[23] Ishaaya, I. (1971) Observation on the phenolixidase system in the armored scales Aonidiella aurantii and Chrysomphalus aonidium. Comparative Biochemistry and Physiology, 39, 935-943.

[24] Lindroth, R.L. (1988) Hydrolysis of phenolic glycosides by mid gut B-glucosidases in papilo glaucus subspecies. Insect Biochemistry, 18, 789-792. doi:10.1016/0020-1790(88)90102-3

[25] Van Asperen, K. (1962) A study of house fly esterase by means of sensitive colourimetric method. Journal of Insect Physiology, 8, 401-416. doi:10.1016/0022-1910(62)90074-4

[26] Simpson, D.R., Bulland, D.L. and Linquist, D.A. (1964) A semi microtechnique for estimation of cholinesterase activity in boll weevils. Annals of the Entomological Society of America, 57, 367-371.

[27] Blackman, R.L. and Eastop, V.F. (2000) Aphids on the world's crops: An identification and information guide. 2nd Edition, Wiley, London.

[28] Hansen, L.M., Lorenstsen, L. and Boelt, B. (2008) How to reduce the incidence of black bean aphids (Aphis fabae Scop.) attacking organic growing field beans (Vicia faba L.) by growing partially resistant bean varieties and by intercropping field beans with cereals. Acta Agriculturae Scandinavica, 58, 359-364.

[29] Goszczynski, W., Cichocka, E. and Leszczynski, B. (2002) Beetroot damage due to the black bean aphid (Aphis fabae Scop) infestation. Electronic Journal of Polish Agricultural Universities, 5, 2.

[30] Cichocka, E., Leszczynski, B., Ciepiela, A.P. and Goszczynski, W. (2002) Response of Aphis fabae Scop. to different broad bean cultivars. Electronic Journal of Polish Agricultural Universities, 5, 1.

[31] Razmjou, J. and Fallahi, A. (2009) Effects of sugar beet cultivar on development and reproductive capacity of Aphis fabae. Bulletin of Insectology, 62, 197-201.

[32] Gazi, G., Cecilia, L. and Aulay, M. (2005) Phenotypic plasticity in host-plant specialization in Aphis fabae. Ecological Entomology, 30, 657-664. doi:10.1111/i.0307-6946.2005.00742.x

[33] Sticher, L., Mauch Mani, B. and Metraux, J.P. (1997) Systemic acquired resistance. Annual Review of Phytopatheology, 35, 235-270.

[34] Dugravot, S., Brunissen, L., Letocart, E., Tjallingii, W.F., Vincent, C., Giordanengo, P. and Cherqui, A. (2007) Local and systemic responses induced by aphids in Solanum tuberosum plants. Entomologia Experimentalis et Appli- cata, 123, 271-277. doi:10.1111/j.1570-7458.2007.00542.x

[35] Will, T., Tjallingii, W.F., Thönnessen, A. and van Bel, A.J.E. (2007) Molecular sabotage of plant defense by aphid saliva. Proceedings of the National Academy of Sciences of USA, 104, 10536-10541. doi:10.1073/pnas.0703535104

[36] Pegadaraju, V., Knepper, C., Reese, J. and Shah, J. (2005) Premature leaf senescence modulated by the arabidopsis PHYTOALEXIN DEFICIENT4 gene is associated with defence against the phloem-feeding green peach aphid. Plant Physiology, 139, 1927-1934. doi:10.1104/pp.105.070433

[37] Francis, F., Haubruge, E. and Gaspaar, C. (2000) Influence of host plants on specialist/generalist aphids on the development of Adalia bipunctata (Coleoptera: Coccinillidae). European Journal of Entomology, 97, 481-485.

[38] Dixon, A.F.G. (1985) Aphid ecology. 2nd Edition. Chapman \& Hall, London.

[39] Cole, R.A. (1997) The relative importance of glucosenolates and amino acids to the development of two aphid pests Brevicoryne brassicae and Myzus persicae on wild and cultivated brassica species. Entomologia Experimentalis et Applicata, 85, 121-133. doi:10.1046/i.1570-7458.1997.00242.x

[40] Fenwick, G.R., Heaney, R.K. and Mullin, W.J. (1983) Glucosinolates and their breakdown products in food and food plants. Critical Reviews in Food Science and Nutrition, 18, 123-201.

[41] Singh, K.B., et al. (2005) Aphid resistance in Medicago truncatula involves antixenosis and phloem-specific, inducible antibiosis, and maps to a single locus flanked by NBS-LRR resistance gene analogs. Plant Physiology, 137, 1445-1455. doi:10.1104/pp.104.051243

[42] Kaloshian, I., Kinsey, M.G., Ullman, D.E. and Williamson, V.M. (1997) The impact of Meul-mediated resistance in tomato on longevity, fecundity and behavior of the potato aphid, Macrosiphum euphorbiae. Entomologia Experimentalis et Applicata, 83, 181-187. doi:10.1046/j.1570-7458.1997.00170.x

[43] Kennedy, G.G. and Kishaba, A.N. (1977) Response of alate melon aphids to resistant and susceptible muskmelon lines. Journal of Economic Entomology, 70, 407410.

[44] Mewis, I., Tokuhisa, J.G., Schultz, J.C., Appel, H.M., Ulrichs, C. and Gershenzon, J. (2006) Gene expression and glucosinolate accumulation in Arabidopsis thaliana in response to generalist and specialist herbivores of different feeding guilds and the role of defense signaling pathways. Phytochemistry, 67, 2450-2462. doi:10.1016/j.phytochem.2006.09.004

[45] Kempema, L.A., Cui, X., Holzer, F.M. and Walling, L.L. (2007) Arabidopsis transcriptome changes in response to phloem-feeding silver leaf whitefly nymphs. Similarities and distinctions in responses to aphids. Plant Physiology, 143, 849-865. doi:10.1104/pp.106.090662

[46] Kim, J.H. and Jander, G. (2007) Myzus persicae (green peach aphid) feeding on Arabidopsis induces the formation of a deterrent indole glucosinolate. The Plant Journal, 
49, 1008-1019. doi:10.1111/j.1365-313X.2006.03019.X

[47] Hunter, M.D. and McNeil, J.N. (1997) Host-plant quality influences diapause and voltinism in a polyphagous insect herbivore. Ecology, 78, 977-986. doi:10.1890/0012-9658(1997)078[0977:HPQIDA]2.0.CO ;2

[48] Tikkanen, O,-P., Niemel, P. and Kernen, J. (2000) Growth and development of a generalist insect herbivore, Operophtera brumata, on original and alternative host plants. Oecologia, 122, 529-536. doi:10.1007/s004420050976

[49] Silva, F., Marcia, O.M. and Marcio, C. (2002) Plant-insect interactions: An evolutionary arms race between two distinct defense mechanisms. Brazilian Journal of Plant Physiology, 14, 71-81.

[50] Jongsma, M.A. and Bolter, C. (1997) The adaptation of insects to plant protease inhibitors. Journal of Insect Physiology, 43, 885-895. doi:10.1016/S0022-1910(97)00040-1

[51] Price, P.W. (1997) Insect ecology. 3rd Edition, John Wiley \& Sons, Inc., New York.

[52] Patankar, A.G., Giri, A.P., Harsulkar, A.M., Sainani, M.N., Deshpande, V.V., Ranjekar, P.K. and Gupta, V.S. (2001) Complexity in specificities and expression of Helicoverpa armigera gut proteinases explains polyphagous nature of the insect pest. Insect Biochemistry and Molecular Biology, 31, 453-464. doi:10.1016/S0965-1748(00)00150-8

[53] Shen, B.Z., Zheng, Z.W. and Dooner, H.K. (2000) A maize sesquiterpene cyclase gene induced by insect herbivory and volicitin: Characterization of wild-type and mutant alleles. Proceedings of the National Academy of Sciences of the United States of America, 97, 1480714812. doi:10.1073/pnas.240284097

[54] Ohshima, T., Hayashi, H. and Chino, M. (1990) Collection and chemical composition of pure phloem sap from Zea mays L. Plant \& Cell Physiology, 31, 735-737.

[55] Tjallingii, W.F. (1995) Regulation of phloem sap feeding by aphids. In: Chapman, R.F. and De Boer, G., Eds., Regulatory mechanisms in insect feeding, Chapman and Hall, New York, 190-209. doi:10.1007/978-1-4615-1775-7 7

[56] Prado, E. and Tjallingii, W.F. (1994) Aphid activities during sieve element punctures. Entomologia Experimentalis et Applicata, 72, 157-165. doi:10.1111/j.1570-7458.1994.tb01813.x

[57] Tjallingii, W.F. (2006) Salivary secretions by aphids interacting with proteins of phloem wound responses. Journal of Experimental Botany, 57, 739-745. doi:10.1093/jxb/erj088

[58] Bridges, M., Jones, A.M.E., Bones, A.M., Hodgson, C., Cole, R., Bartlet, E., Wallsgrove, R., Karapapa, V.K., Watts, N. and Rossiter, J.T. (2002) Spatial organization of the glucosinolate-myrosinase system in brassica specialist aphids is similar to that of the host plant. The Royal Society Proceedings. B, Biological Sciences, 269, 187-191. doi:10.1098/rspb.2001.1861

[59] De Bruxelles, G.L. and Roberts, M.R. (2001) Signals regulating multiple responses to wounding and herbivores.
Critical Reviews in Plant Sciences, 20, 487-521.

[60] Nishida, R. (2002) Sequestration of defensive substances from plants by lepidoptera. Annual Review of Entomology, 47, 57-92. doi:10.1146/annurev.ento.47.091201.145121

[61] Miles, P.W. (1999) Aphid saliva. Biological Reviews of the Cambridge Philosophical Society, 74, 41-85.

[62] Miles, P.W. and Harrewijn, P. (1991) Discharge by aphids of soluble secretions into dietary sources. Entomologia Experimentalis et Applicata, 59, 123-134. doi:10.1111/j.1570-7458.1991.tb01495.x

[63] Baumann, L. and Baumann, B. (1995) Soluble salivary protein secreted by Schizaphis graminum. Entomologia Experimentalis et Applicata, 77, 57-60. doi:10.1111/j.1570-7458.1995.tb01985.x

[64] Urbanska, A., Tjallingii, W.F. and Leszczynski, B. (1994) Application of agarose-sucrose gels for investigation of aphid salivary enzymes. In: Hamilton, K., et al., Eds., Aphids and Other Homopterous Insects, Vol. 4, Polish Academy of Science, Skiernewice, 81-87.

[65] Madhusudhan, V.V. and Miles, P.W. (1998) Mobility of salivary components as a possible reason for differences in response of alfalfa to the spotted alfalfa aphid and pea aphid. Entomologia Experimentalis et Applicata, 86, 2539. doi:10.1046/j.1570-7458.1998.00262.x

[66] Kornemann, S. (2005) Untersuchung zu einem allgemeinen Modell der Siebelementwund-verschlus-sunterdru"ckung durch Blattla"use. Ph.D. Thesis, Justus Liebig University, Gießen.

[67] Kus'nierczyk, A., Winge, P., Jørstad, T.M., Troczyn'ska, J., Rossiter, J.T. and Bones, A.M. (2008) Towards global understanding of plant defence against aphids-timing and dynamics of early Arabidopsis defence responses to cabbage aphid (Brevicoryne brassicae) attack. Plant, Cell \& Environment, 31, 1097-1115. doi:10.1111/j.1365-3040.2008.01823.x

[68] Goggin, F.L. (2007) Plant-aphid interactions: Molecular and ecological perspectives. Current Opinion in Plant Biology, 10, 399-408. doi:10.1016/j.pbi.2007.06.004

[69] Hori, K. (1976) Plant growth-regulating factor in the Salivary gland of several heteropterous insects. Comparative Biochemistry and Physiology Part B: Comparative Biochemistry, 53, 435-438.

[70] Urbanska, A., Tjallingii, W.F., Dixon, A.F.G. and Leszczynski (1998) Phenol oxidising enzymes in the grain aphid's saliva. Entomologia Experimentalis et Applicata, 86, 197-203. doi:10.1046/j.1570-7458.1998.00281.x

[71] Harmel, N., Le'tocart, E., Cherqui, A., Giordanengo, P., Mazzucchetlli, G., Guillonneau, F., De Pauw, E., Haubruge, E. and Francis, F. (2008) Identification of pahid salivary proteins: A proteomic investigation of Myzus persicae. Insect Molecular Biology, 17, 165-174. doi:10.1111/j.1365-2583.2008.00790.x

[72] Ni, X., Quisenberry, S.S., Pornkulwat, S., Figarola, J., Skoda, S.R. and Foster, J.E. (2000) Hydrolase and oxidoreductase activities in Diuraphis noxia and Rhopalosiphum padi (Hemiptera: Aphididae). Annals of the Entomological Society of America, 93, 595-601. doi:10.1603/0013-8746(2000)093[0595:HAORAI]2.0.C $\underline{\mathrm{O} ; 2}$ 
[73] Miles, P.W. and Peng, Z. (1989) Studies on the salivary physiology of plant bugs: Detoxification of phytochemicals by the salivary peroxidase of aphids. Journal of Insect Physiology, 35, 865-872. doi:10.1016/0022-1910(89)90102-9

[74] Peng, Z. and Miles, P.W. (1991) Oxidases in the gut of an aphid, Macrosiphum rosae (L.) and their relation to dietary phenolics. Journal of Insect Physiology, 37, 779-787. doi:10.1016/0022-1910(91)90113-E

[75] Lamabadusuriya, M.R. (2009) Development of sample collection methods and preliminary identifications of Aphid salivary proteins. Master of Science Thesis, Kansas State University, Manhattan.

[76] Mattiacci, L., Dicke, M. and Posthumus, M.A. (1995) $\beta$-Glucosidase: An elicitor of herbivore-induced plant odor that attracts host-searching parasitic wasps. Proceedings of the National Academy of Sciences of the United States of America, 92, 2036-2040. doi:10.1073/pnas.92.6.2036

[77] Sales, M.P., Gerhardt, I.R., Grossi-de-Sá, M.F. and Xavier-Filho, J. (2000) Do legume storage proteins play a role in defending seeds against bruchids? Plant Physiology, 124, 515-522. doi:10.1104/pp.124.2.515

[78] Franco, O.L., Rigden, D.J., Melo, F.R. and Grossi-de-Sá, M.F. (2002) Plant alpha-amylase inhibitors and their interaction with insect alpha-amylases-structure, function and potential for crop protection. European Journal of Biochemistry, 269, 397-412. doi:10.1046/i.0014-2956.2001.02656.x

[79] Scott, J.G. and Wen, Z.M. (2001) Cytochromes P450 of insects: The tip of the iceberg. Pest Management Science, 57, 958-967. doi:10.1002/ps.354

[80] Urbanska, A., Leszczynski, B., Tjallingii, W.F. and Matok, H. (2002) Probing behavior and enzymatic defence of the grain aphid against cereal phenolics. Electronic Journal of Polish Agricultural Universities, 5. http://www.ejpau.media.pl

[81] Classen, D., Arnason, J.T., Serratos, J.A., Lambert, J.D.H., Nozzolillo, C. and Philogène, B.J.R. (1990) Correlation of phenolic acid content of maize to resistance to Sitophilus zeamais, the maize weevil, in CIMMYT's collections. Journal of Chemical Ecology, 16, 301-315. doi:10.1007/BF01021766

[82] Dreyer, D.L. and Jones, K. (1981) Feeding deterrence of flavonoids and related phenolics toward Schizaphis graminum and Myzus persicae: Aphid feeding deterrents from wheat. Phytochemistry, 20, 2489-2493. doi:10.1016/0031-9422(81)83078-6

[83] Todd, G.W., Getahun, A. and Cress, D.C. (1971) Resistance in barley to the greenbug Schizaphis graminum. 1. Toxicity of phenolic and flavonoid compounds and related substances. Annals of the Entomological Society of America, 64, 718-722.

[84] De Bruxelles, G.L. and Roberts, M.R. (2001) Signals regulating multiple responses to wounding and herbivores. Critical Reviews in Plant Sciences, 20, 487-521.

[85] Alborn, H.T., Turlings, T.C.J., Jones, T.H., Stenhagen, G., Loughrin, J.H. and Tumlinson, J.H. (1997) An elicitor of plant volatiles from beet armyworm oral secretion. Science, 276, 945-949. doi:10.1126/science. 276.5314 .945

[86] Way, M.J., Cammell, M.E., Taylor, L.R. and Woiwod, I.P. (1981) The use of egg counts and suction trap samples to forecast the infestation of spring-sown field beans, Vicia faba, by the black bean aphid, Aphis fabae. Annals of Applied Biology, 98, 21-34. doi:10.1111/j.1744-7348.1981.tb00419.x

[87] Hoover, D. (1990) Cholinesterases and cholinesterase inhibitors. In: Craig, C.R. and Stitzel, R.E., Eds., Modern Pharmacology, Little, Brown and Co., Boston, 165-178.

[88] Zahavi, M., Tahori, A.S. and Klimer, F. (1972) An acetylcholinesterase sensitive to sulfhydryl inhibitors. Biochimica et Biophysica Acta, 276, 577-583. doi:10.1016/0005-2744(72)91024-8

[89] Ogenga-Latego, M.W., Baliddawa, C.W. andAmpofo, J.K.O. (1993) Factors influencing the incidence of black bean aphid Aphis fabae scop. On common beans intercropped with Maize. African Crop Science Journal, 1, 49-58. 